\title{
Isolation and Enrichment of Circulating Fetal Cells for NIPD: An Overview
}

\author{
Giulia Sabbatinelli ${ }^{1}$, Donatella Fantasia ${ }^{2}$, Chiara Palka ${ }^{3}$, Elisena Morizio ${ }^{4}$, Melissa Alfonsi ${ }^{3}$ \\ and Giuseppe Calabrese ${ }^{2,4, *}$
}

1 Dipartimento di Neuroscienze, Imaging \& Scienze Cliniche, Scuola Superiore G. D'Annunzio, University of Chieti, 66100 Chieti, Italy; giulia.sabbatinelli@unich.it

2 UOSD Genetica Oncoematologica, Dipartimento di Oncologico-Ematologico, Ospedale Spirito Santo, ASL Pescara, 65124 Pescara, Italy; donatella.fantasia@asl.pe.it

3 UOC Genetica Medica, Ospedale S.S. Annunziata, ASL2 Chieti, 66100 Chieti, Italy; chiara.palka@asl2abruzzo.it (C.P.); melissa.alfonsi@gmail.com (M.A.)

4 Genetica Medica, Dipartimento di Tecnologie Avanzate in Medicina e Odontoiatria, School of Medicine, University of Chieti, 66100 Chieti, Italy; elisena.morizio@unich.it

* Correspondence: giuseppe.calabrese@unich.it

check for updates

Citation: Sabbatinelli, G.; Fantasia,

D.; Palka, C.; Morizio, E.; Alfonsi, M.;

Calabrese, G. Isolation and

Enrichment of Circulating Fetal Cells for NIPD: An Overview. Diagnostics 2021, 11, 2239. https://doi.org/

10.3390/diagnostics11122239

Academic Editor: Ming Chen

Received: 15 November 2021

Accepted: 28 November 2021

Published: 30 November 2021

Publisher's Note: MDPI stays neutral with regard to jurisdictional claims in published maps and institutional affiliations.

Copyright: (C) 2021 by the authors. Licensee MDPI, Basel, Switzerland. This article is an open access article distributed under the terms and conditions of the Creative Commons Attribution (CC BY) license (https:/ / creativecommons.org/licenses/by/ $4.0 /)$.

\begin{abstract}
Prenatal diagnosis plays a crucial role in clinical genetics. Non-invasive prenatal diagnosis using fetal cells circulating in maternal peripheral blood has become the goal of prenatal diagnosis, to obtain complete fetal genetic information and avoid risks to mother and fetus. The development of high-efficiency separation technologies is necessary to obtain the scarce fetal cells from the maternal circulation. Over the years, multiple approaches have been applied, including choice of the ideal cell targets, different cell recovering technologies, and refined cell isolation yield procedures. In order to provide a useful tool and to give insights about limitations and advantages of the technologies available today, we review the genetic research on the creation and validation of non-invasive prenatal diagnostic testing protocols based on the rare and labile circulating fetal cells during pregnancy.
\end{abstract}

Keywords: prenatal diagnosis; circulating fetal cells; NIPD

\section{Introduction}

During the early stages of fetal development, some cells migrate from the fetus to the maternal circulation and may represent an interesting target for non-invasive prenatal diagnosis (NIPD).

However, despite technological advances, an effective standardized test suitable for routine clinical practice is not yet available. An obstacle is the small number of fetal cells present in the maternal circulation and their extreme fragility, which can lead to loss during sample handling and the absence of a specific fetal marker.

Non-invasive prenatal testing based on circulating fetal cell-free DNA has been commercially available since 2011 and offers the opportunity to radically change prenatal screening. However, the introduction into actual clinical practice is challenging because of cost, differences in the scope of abnormalities detectable, and integration into existing testing [1,2]. Recently, the analysis of fetal cells from peripheral maternal blood has been shown to be more effective in helping to identify fetal aneuploidy, microdeletion syndromes, hemoglobinopathy, and blood groups than cffDNA, due to their intact fetal genome, free from maternal DNA contamination [3].

In this review, we briefly retrace the steps of this long journey, which has been characterized by failures and technological progress and has lasted decades.

\section{Limitations and Difficulties}

The great potential of circulating fetal cells in non-invasive prenatal testing was identified in 1969 by Walknowska et al., with the discovery of fetal lymphocytes with a 
male karyotype in the maternal circulation [4], even though the discovery of fetal cells is attributed to Zipursky et al., 10 years earlier [5].

This started the chapter on the study of circulating fetal cells. The greatest limitations have been the small number of fetal cells, their dubious origin, and the difficulty of developing an adequate isolation strategy due to the lack of specific markers and the fragility of the fetal cells.

A variety of fetal cell types, such as trophoblastic cells, lymphocytes, hematopoietic stem cells (HMCs), and fetal nucleated erythrocytes (fnRBCs), can be found in the maternal circulation [6]. However, it is essential to remember that ideal target cells for non-invasive investigation need to express characteristics that demonstrate their fetal origin, such as short half-life, early appearance in the maternal circulation, relatively distinct cell morphology, a single nucleus with complete genetic makeup, or specific cellular markers. The fetal cell lines found in the mother's blood have different characteristics, and the biggest obstacle is the separation of these fetal cells from those of the mother; this can significantly influence the accuracy of investigations.

\section{Quantification of Fetal Cells in Maternal Blood}

The entry of fetal cells into the maternal circulation is a physiological phenomenon called microchimerism, which occurs as early as $4-6$ weeks into pregnancy. Fetal cells have been detected in maternal blood from 4 weeks of gestation until 39 days after delivery. The optimal time for recovery remains to be determined [7-14]. The total number of fetal cells in maternal blood was comprehensively verified in 2001 by Krabchi et al. via a method that avoided the cell enrichment of blood samples, but using molecular cytogenetic techniques such as fluorescence in situ hybridization (FISH) and primed in situ labeling (PRINS). Krabchi et al. found that there are 2-6 fetal cells/mL of maternal blood in the second trimester of a normal pregnancy [15]. However, fetal and placental abnormalities, such as fetal aneuploidy, preeclampsia, maternal-fetal isoimmunization, and other maternal obstetric complications such as gestational diabetes and bleeding, result in an increase in the number of fetal cells of different types in the maternal circulation [16-18].

Numerous studies have verified this condition. In particular, according to Krabchi, in the case of an aneuploid fetus, the number of fetal cells is approximately 6-32 per $\mathrm{mL}$ of maternal blood ( 1 fetal cell for every 200/250 maternal cells after enrichment), considering all the fetal cells present and independent of their morphology. This condition does not currently have a clear explanation but is supposed to depend on a modification of the microscopic architecture of the placenta. Alternatively, it may be related to the size of fetal cells, which differs from those of cytogenetically normal fetuses of the same gestational age $[18,19]$.

\section{Fetal Cell Types and Strategies for Isolation and Enrichment}

Herzenberg et al. were the first to demonstrate the enrichment of fetal leukocytes from maternal blood in 1979 using fluorescence-activated cell sorting (FACS) [20]; however, the most studied cell types are erythroblasts (nRBCs) and trophoblasts. A summary of the types of fetal cells identified and isolated from the maternal circulation and the most commonly applied markers are shown in Table 1.

\subsection{Trophoblast}

Trophoblasts were the first cell type identified. Cytotrophoblast-derived cells are mononuclear, invade the uterine wall and spiral arteries, and spill into maternal blood.

One of the distinguishing features of trophoblastic cells is the expression of cytokeratins (CKs). 
Table 1. Fetal cell lines isolated from maternal peripheral blood and markers most commonly applied for validation of NIPD.

\begin{tabular}{|c|c|c|c|}
\hline $\begin{array}{l}\text { Fetal Cell Types in } \\
\text { Maternal Blood }\end{array}$ & Markers & Advantages & Drawbacks \\
\hline Lymphoid progenitors & $\begin{array}{l}\text { CD34 }[21,22] \\
\text { CD38 }[21,22]\end{array}$ & In vitro proliferation [23] & $\begin{array}{c}\text { Long-term survival [21,22]; } \\
\text { Not easy distinguishable from } \\
\text { maternal cells [23] }\end{array}$ \\
\hline $\begin{array}{c}\text { Hematopoietic } \\
\text { stem/progenitor cells }\end{array}$ & CD34 [6,21,24-28] & In vitro proliferation [23] & $\begin{array}{c}\text { Long-term survival [21]; } \\
\text { Not easy distinguishable from } \\
\text { maternal cells [23] }\end{array}$ \\
\hline Mesenchymal stem cells & $\begin{array}{c}\text { Vimentin }[25,29] \\
\text { Fibronectin }[25] \\
\text { Vascular cell adhesion } \\
\text { molecule }[25,28] \\
\text { CD14 }[25,29] \\
\text { CD45 }[25,29]\end{array}$ & $\begin{array}{l}\text { In vitro proliferation and } \\
\text { differentiation }[25,29,30] ; \\
\text { Great therapeutical } \\
\text { potential [25] }\end{array}$ & $\begin{array}{l}\text { Very low number }[25,29] \\
\text { Engraftment in maternal } \\
\text { tissue soon after } \\
\text { transplacental passage [29] }\end{array}$ \\
\hline Leukocytes & $\begin{array}{l}\text { HLA antigens }[20,28,31,32] \\
\text { CD45 }[28,33]\end{array}$ & $\begin{array}{l}\text { Transplacental passage [4]; } \\
\text { In vitro proliferation [4] }\end{array}$ & $\begin{array}{l}\text { Long persistence in maternal } \\
\text { blood [21] }\end{array}$ \\
\hline Nucleated red blood cells & $\begin{array}{c}\zeta \text { and } \varepsilon \text { chain of embryonic } \\
\mathrm{Hb} \text { [34-37] } \\
\gamma \text { chain of HbF [36] } \\
\text { CD71 [38-41] } \\
4 \text { B9 [42] } \\
\text { i-antigen [38] } \\
\text { CD147 [43] } \\
\text { Gly A [39] }\end{array}$ & $\begin{array}{c}\text { Short half-life [6]; } \\
\text { Single nucleus [6]; } \\
\text { Early appearance in maternal } \\
\text { blood [6]; } \\
\text { Surface and intracellular } \\
\text { markers }[34,36-39,41-43]\end{array}$ & $\begin{array}{l}\text { Low number in maternal } \\
\text { blood [6] }\end{array}$ \\
\hline $\begin{array}{l}\text { Extravillous cytotrophoblasts } \\
\text { (EVTs) }\end{array}$ & $\begin{array}{c}\text { H315 [44] } \\
\text { GB17 [45] } \\
\text { GB25 [45] } \\
\text { Cytokeratins [46-48] } \\
\text { CD105 [48] } \\
\text { Human leukocyte G } \\
\text { antigen [49,50] } \\
\text { CD141 [51] }\end{array}$ & $\begin{array}{l}\text { Specific intracellular } \\
\text { markers [52]; } \\
\text { Relatively distinctive cell } \\
\text { morphology (size) [53] }\end{array}$ & $\begin{array}{l}\text { Passage in maternal blood is } \\
\text { uncommon phenomenon in } \\
\text { all pregnancies [52-54]; } \\
\text { Placental origin } \\
\text { (1\% mosaicism) [55] }\end{array}$ \\
\hline
\end{tabular}

Sargent et al. and Johnson et al. used an antibody against trophoblast-specific H315 surface antigen, which later proved insufficient for adequate cell separation [44,46,47].

Cacheux et al. recovered trophoblasts from maternal blood using immunomagnetic leukocyte depletion and flow cytometry with the anti-trophoblast antibodies GB17 and GB25. However, Y chromosome identification by FISH showed a rate of only $4.25 \%$ [45]. Other studies report the use of human leukocyte $G$ antigen to enrich circulating trophoblasts from the maternal circulation $[37,38,42,50]$. An additional isolation strategy was based on fetal trophoblast cell size [55].

The limitations currently associated with the use of these cells are their extremely low numbers in the mother's blood. In addition, they are difficult to isolate because they become trapped in the lungs and are rapidly eliminated from the maternal circulation. Furthermore, the passage of trophoblastic cells does not appear to be a common phenomenon in all pregnancies [52-54].

The major disadvantage of using CKs and other intracellular antigens is the need to make membranes of fragile fetal cells permeable to antibody molecules.

In addition, trophoblastic cells, being of placental origin, have a $1 \%$ incidence of mosaicism, similar to that found in chorionic villus sampling (CVS) [55]. 


\subsection{Erythroblast}

Historically, nRBCs have been the most studied cells for NIPD. The first evidence of immature erythrocytes circulating in maternal blood dates back to 1957 in Kleinhauer's studies [36]. The fnRBCs are the first hematopoietic cells to be produced during fetal development. Their passage through the maternal-placental interface is predominant over other fetal cell types, such as leukocytes and trophoblasts. They also have a short half-life (25-35 days), which does not allow their persistence in the maternal circulation [56,57]. In addition, they have a single nucleus with a complete genetic makeup and relatively specific intracellular and surface markers. Due to these characteristics, fnRBCs appear highly interesting targets for NIPD [6].

\section{Technical Approaches for Isolation or Enrichment of Fetal Cells 4.1. MACS and FACS}

In the 1990s, the techniques of choice for fnRBC enrichment were FACS and magnetic activated cell sorting (MACS). Bianchi et al. first used a monoclonal antibody against CD71 to enrich nRBCs [58]; selection by only transferrin receptor recognition was subsequently used by Ganshirt-Ahlert et al. [34], but this antibody also recognizes some adult cells. To improve the purity, Purwosunu et al. added the depletion of maternal cells and fetal lymphocytes with anti-CD45 antibody prior to positive selection for CD71 [54]. Many different positive and negative enrichment strategies have been explored, including positive enrichment by MACS with monoclonal antibodies to CD71 or glycophorin A (Gly A) or detection by FACS using monoclonal antibodies to fetal hemoglobin (HbF). Some examples are the work of Martel-Petit et al., who identified a fetus with cystic fibrosis by studying fnRBCs [39], and Souza et al., who used a combination of antibodies to increase the specificity of fnRBC selection [40].

Studies have shown that the best results are obtained with magnetically based separation systems as compared to flow-sorting [17]. However, the recovery rate of fnRBCs is low for clinical implementation because the key to the enrichment of cell populations by FACS and MACS is the selectivity of the antibody [59].

\subsection{Density Gradient Centrifugation}

The fnRBCs have a density higher than that of white blood cells. The most commonly used gradients have been made using Ficoll and Percoll at different densities $(1.077 \mathrm{~g} / \mathrm{mL}$, $1.083 \mathrm{~g} / \mathrm{mL}, 1.119 \mathrm{~g} / \mathrm{mL}$ ). In this case, the buffers that are used have different cell recovery rates. Through this approach, up to 1000-fold enrichment in the fetal cell population can be achieved, but there is still significant contamination with maternal cells [11]. Furthermore, it appears that the relative density of fetal cells can change during the preparation of blood samples, making it difficult to standardize density gradient centrifugation procedures.

Sitar et al. used non-physiological conditions to modify the cell mean corpuscular volume of red blood cells and increase mononuclear cell densities. To overcome the drawbacks inherent in a standard centrifuge tube, they used a cell separation device to isolate fetal cells in a single density gradient centrifugation [60]. The enrichment by centrifugation on a density gradient was subsequently combined with the application of antibodies for positive selection of fnRBCs. Our group used an anti i-antigen antibody in combination with antibodies for CD71+, CD45-, and CD19- cells on samples previously enriched by centrifugation on a density gradient. Positive fnRBCs were recovered by micromanipulation [38]. The blood group I-antigen is a surface marker of great interest for the identification of fnRBCs. Adult human red blood cells fully express I-antigens and contain only a few i-antigens, whereas fetal and neonatal red blood cells predominantly express the latter [61]. After birth, i-antigen is gradually replaced by I-antigen, but this may not occur if the subject has thalassemia major, hypoplasia anemia, or acute leukemia $[62,63]$.

We also performed a clinical feasibility study on 172 women with a single pregnancy prior to any invasive prenatal diagnostic (IPD) procedure to investigate the presence of fetal aneuploidies. Fetal cell enrichment was performed by transfer under non-physiological 
conditions and density gradient centrifugation. Trisomic fetal cells were identified by dual-probe FISH analysis [61]. Seven of the samples exhibited fetal aneuploidy, which was confirmed by invasive prenatal diagnostic procedures. After enrichment of fetal cells, the frequency of trisomic cells was at least double in samples from aneuploid pregnancies (range 0.38-0.90\%) compared to samples from normal pregnancies $(\leq 0.18 \% ; p<0.01)$. One false-negative result was also obtained. Overall, the FISH analysis had a detection rate of $7 / 8(87.5 \%, 95 \%$ CI 42-99\%) [64]. In a subsequent study, we applied the same fetal cell enrichment approach to a cohort of pregnant women at high risk based on a contingent test. FISH analysis identified 7 abnormal and 39 normal cases, with $100 \%$ specificity and 100\% sensitivity [65]. In a recent study, Nemescu et al. combined double-density gradient centrifugation with paramagnetic selection by the conversion of hemoglobin $(\mathrm{Hb})$ into methemoglobin [41]. The advantage of the study was a simple approach with low cell manipulation, and the suggestive results from a limited number of isolated fetal cells analyzed need further investigation on a large cohort of patients.

\subsection{Other Methods}

Other methods used for fetal cell enrichment include avidin-biotin columns, magnetic iron-fluid, and lectin-induced separation. To improve enrichment, some researchers have sought more specific antibodies or biochemical markers, whereas some have relied on chemical assays for analysis, such as 2,3-bisphosphoglycerate (BPG) [66], carbonic anhydrase (CA) [67,68], and thymidine kinase (TK) [69]. It is thought that, in a sequential peroxidase reaction, BPG exposes fetal heme-iron to oxidation by identifying $\mathrm{HbF}$ by forming a colored substrate-associated complex. In addition, fetal cells can be differentiated from adult cells based on TK enzyme activity, which is virtually absent in adult cells, using a fluorescent analogue of thymidine. The fnRBCs are also less susceptible to ammonium chloride lysis than adult nRBCs because CA activity is five times lower and acetozolamide permeability approximately ten times greater. Several studies [70,71] have used soybean agglutinin (SBA), which recognizes $\mathrm{N}$-acetylgalactosamine and galactose, demonstrating high specificity for erythroblasts and eliminating leukocytes from the sample.

However, lectin-induced separation should be combined with another enrichment technique, usually density gradient centrifugation.

The possibility of using an erythropoietin assay has also been explored [72]. However, to date, most researchers still use anti-CD71 or anti-globin antibodies for the enrichment of fnRBCs.

Other researchers have isolated a fair number of nRBCs by charge flow separation, which allows cells to be sorted according to their characteristic surface charge densities $[73,74]$.

\section{New Approaches}

In recent years, numerous studies have reported the implementation of technology in the field of microfluidics. In fetal cell isolation, microfluidics allows the separation of cells based on size, deformability, and electrical and optical properties [75,76]. Antibodies with specific cellular markers can also be used [77]. Wang et al. were able to isolate 24 fnRBCs per milliliter of maternal blood in media using gelatin-coated microspheres, with anti-CD147 as a specific recognition molecule. Cells that bind to the microspheres are separated through a spiral microfluidic chip, based on the size difference between the microspheres binding fnRBCs and white blood cells. The release of fetal cells from the microspheres is achieved by enzymatic treatment. A fetal cell capture efficiency of approximately $81 \%$, a purity of $83 \%$, and a viability of cell release $>80 \%$ were calculated using spiked samples [78]. The technology is very suggestive, and robust evidence is needed about its practical application when tested on a large series of patients.

Another fascinating technological innovation is the Cell Reveal ${ }^{\mathrm{TM}}$ system, a siliconbased nanostructured microfluidic that uses immunoaffinity to capture trophoblasts and $\mathrm{fn}$ RBCs with specific antibodies. Huang et al. tested this technology, isolating 14-32 fnRBCs $/ 4 \mathrm{~mL}$ 
and 1-44 EVT/4 mL of maternal blood. The fetal origin of the cells was confirmed by FISH on chip. The identified cells were retrieved by an automated cell harvester for molecular genetic analysis, such as comparative genomic array hybridization (aCGH) and next-generation sequencing (NGS) [79]. The cell capture rate was evaluated in spiking assays and estimated to be $88.1 \%$ [80].

In a recent study, Gur et al. presented a two-tiered microchip system that reduces sample preparation steps while implementing purity, using ETVs model cell lines. The system allows for direct processing of a whole blood sample and appears versatile enough to target a variety of antigens to achieve a high rate of cell recovery [81].

Microfluidic techniques are already used in many laboratories because of the considerable advantages they present, all of which are derived from the small volumes of liquid treated, high control of flow, less time needed to analyze a product, lower costs of reagents and waste products, greater control of concentrations and molecular interactions, and the possibility of performing parallel processes. Further development of such devices appears to be very promising.

However, limitations of approaches based on microfluidic systems remain, including the inability to directly process a standard tube of blood sample without an initial volume reduction step, the use of a single antibody for cell capture, and the retrieval of cells individually for downstream analysis [82]. In Table 2 a list of approaches for fetal cell isolation/enrichment is reported.

Table 2. A summary of technical approaches of isolation or enrichment of fetal cells in the maternal circulation.

\begin{tabular}{|c|c|c|c|}
\hline Fetal Cell Type & Isolation/Enrichment Technique & Purity and Recovery Rates & References \\
\hline \multirow{9}{*}{ fnRBCs } & MACS & $\mathrm{N} / \mathrm{A}$ & {$[34,41,83]$} \\
\hline & FACS & $\mathrm{N} / \mathrm{A}$ & [58] \\
\hline & Density gradient centrifugation & $\begin{array}{c}82 \pm 6.4 \% \text { purity }[51] \\
84 \pm 4 \% \text { recovery rate [51] } \\
32.5 \pm 11.6 \text { recovered cells [61] }\end{array}$ & {$[60,64-66,71]$} \\
\hline & High molecular filter method & $46.3 \pm 25.1$ recovered cells & [71] \\
\hline & Morphology-based micromanipulation & Average 4.1 recovered cells & [84] \\
\hline & Charge flow separation & $\begin{array}{c}0.503 \pm 0.264 \text { purity } \\
11,409 \pm 7.684 \text { recovered cells }\end{array}$ & [73] \\
\hline & Lateral magnetophoretic microseparator & $\begin{array}{c}87.8 \% \text { purity } \\
1-396 \text { recovered cells }\end{array}$ & [85] \\
\hline & Microfluidics & $\begin{array}{c}83 \% \text { purity [68] } \\
81 \% \text { recovery rate [68] } \\
88.17 \% \text { recovery rate [70] } \\
\end{array}$ & [78-80] \\
\hline & Hyperaggregation & $\mathrm{N} / \mathrm{A}$ & [86] \\
\hline \multirow{5}{*}{ Trophoblasts } & MACS & $\mathrm{N} / \mathrm{A}$ & [51] \\
\hline & FACS & $\mathrm{N} / \mathrm{A}$ & [45] \\
\hline & $\begin{array}{l}\text { Isolation by size of epithelial } \\
\text { tumor/trophoblastic cells (ISET) }\end{array}$ & $\begin{array}{l}50.7 \% \text { recovery rate }[76] \\
48.1 \% \text { recovery rate }[77]\end{array}$ & {$[50,87-89]$} \\
\hline & $\begin{array}{l}\text { Trophoblast retrieval and isolation from the } \\
\text { cervix (TRIC) }\end{array}$ & $\begin{array}{c}99 \% \text { purity [90] } \\
106 \% \pm 13 \text { recovery rate [90] } \\
675(\mathrm{IQR}, 399-1010) \text { trophoblast yield [91] } \\
97.9 \% \text { purity [91] }\end{array}$ & {$[90,91]$} \\
\hline & Microfluidics & 1-32 EVT/2 mL & [79] \\
\hline \multirow{4}{*}{ Fetal cells * } & Avidin-biotin immunoaffinity column & Enrichment up to 1000 -fold & [92] \\
\hline & Telomerase depletion assay & $\mathrm{N} / \mathrm{A}$ & [93] \\
\hline & data Lectin-based method & $7.8 \pm 8.5$ recovered cells & [70] \\
\hline & Ikonoscope & $\mathrm{N} / \mathrm{A}$ & [94] \\
\hline
\end{tabular}

$\mathrm{N} / \mathrm{A}$; not available. ${ }^{*}$ not otherwise identified. 


\section{Conclusions}

Fetal cells, although rare, circulate in the blood of pregnant women in variable numbers. Although we have not yet developed a test that allows for routine clinical isolation of fetal cells, it is possible to enrich and analyze them to determine the blood types, the presence of hemoglobinopathy, and the genetic status of the fetus. Over the years, different strategies for isolating fetal cells have been tested. However, invasive methods, such as CVS and amniocentesis, are still the most reliable methods for prenatal diagnosis of chromosomal aberrations and copy number variations (CNVs). However, these invasive procedures carry a risk of miscarriage and cause fear and stress in the pregnant woman.

With technological progress, it has become possible to recover, identify, and genetically analyze even a few circulating fetal cells from a few milliliters of maternal blood. Whole genome amplification (WGA) allows the use of rare fetal cells for downstream genetic analysis, such as aCGH or NGS. In the near future, NIPD using circulating fetal cells could enter the diagnostic scenario, leading to long-awaited change.

Author Contributions: Writing of the paper: G.S., G.C.; Supervision of the manuscript: E.M., M.A., C.P., D.F. All authors have read and agreed to the published version of the manuscript.

Funding: This research received no external funding.

Acknowledgments: Authors wish to thank 3M Foundation for the generous gift of Fluorinert fluid. Authors are really grateful to G. Palka and G. Sitar for clever support and great discussion on NIPD.

Conflicts of Interest: The authors declare no conflict of interest.

\section{References}

1. Cuckle, L.S.; Benn, P.; Pergament, E. Cell-free DNA screening for fetal aneuploidy as a aclinical service. Clin. Biochem. 2015, 48, 932-941. [CrossRef]

2. Chitty, L.S.; Wright, D.; Hill, M.; Verhoef, T.I.; Dalet, R.; Lewis, C.; Mason, S.; McKay, F.; Jenkins, L.; Howarth, A.; et al. Uptake, outcomes, and costs of implementing non-invasive prenatal testing for Down's syndrome into NHS maternity care: Prospective cohort study in eight diverse maternity units. BMJ 2016, 354, i3426. [CrossRef]

3. Chen, F.; Liu, P.; Gu, Y.; Zhu, Z.; Nanisetti, A.; Lan, Z.; Huang, Z.; Liu, J.S.; Kang, X.; Deng, Y.; et al. Isolation and whole genome sequencing of fetal cells from maternal blood towards the ultimate non-invasive prenatal testing. Prenat. Diagn. 2017, 37, 1311-1321. [CrossRef]

4. Walknowska, J.; Conte, F.; Grumbach, M. Practical and theoretical implications of fetal/maternal lymphocyte transfer. Lancet 1969, 293, 1119-1122. [CrossRef]

5. Zipursky, A.; Hull, A.; White, F.D.; Israels, L.G. Fœtal Erythrocytes in the Maternal Circulation. In Rhesus Haemolytic Disease; Springer: Dordrecht, The Netherlands, 1975; pp. 143-145. [CrossRef]

6. Huang, Z.; Fong, C.-Y.; Gauthaman, K.; Sukumar, P.; Choolani, M.; Bongso, A. Novel approaches to manipulating foetal cells in the maternal circulation for non-invasive prenatal diagnosis of the unborn child. J. Cell. Biochem. 2011, 112, 1475-1485. [CrossRef]

7. Ariga, H.; Ohto, H.; Busch, M.P.; Imamura, S.; Watson, R.; Reed, W.; Lee, T.-H. Kinetics of fetal cellular and cell-free DNA in the maternal circulation during and after pregnancy: Implications for noninvasive prenatal diagnosis. Transfusion 2001, 41, 1524-1530. [CrossRef]

8. Ganshirt-Ahlert, D.; Smeets, F.W.; Dohr, A.; Walde, C.; Steen, I.; Lapucci, C.; Falcinelli, C.; Sant, R.; Velasco, M.; Garritsen, H.S.; et al. Enrichment of fetal nucleated red blood cells from the maternal circulation for prenatal diagnosis: Experiences with triple density gradient and MACS based on more than 600 cases. Fetal Diagn. Ther. 1998, 13, 276-286. [CrossRef] [PubMed]

9. Lo, Y.M.; Tein, M.S.; Lau, T.K.; Haines, C.J.; Leung, T.N.; Poon, P.M.; Wainscoat, J.S.; Johnson, P.J.; Chang, A.M.; Hjelm, N.M. Quantitative analysis of fetal DNA in maternal plasma and serum: Implications for noninvasive prenatal diagnosis. Am. J. Hum. Genet. 1998, 62, 768-775. [CrossRef] [PubMed]

10. Hamada, H.; Arinami, T.; Kubo, T.; Hamaguchi, H.; Iwasaki, H. Fetal nucleated cells in maternal peripheral blood: Frequency and relationship to gestational age. Hum. Genet. 1993, 91, 427-432. [CrossRef] [PubMed]

11. Bianchi, D.W.; Williams, J.M.; Sullivan, L.; Hanson, F.W.; Klinger, K.W.; Shuber, A.P. PCR Quantitation of Fetal Cells in Maternal Blood in Normal and Aneuploid Pregnancies. Am. J. Hum. Genet. 1997, 61, 822-829. [CrossRef]

12. Shulman, L.P.; Phillips, O.P.; Tolley, E.; Sammons, D.; Wachtel, S.S. Frequency of nucleated red blood cells in maternal blood during the different gestational ages. Hum. Genet. 1998, 103, 723-726. [CrossRef] [PubMed]

13. Kuo, P.-L. Frequencies of Fetal Nucleated Red Blood Cells in Maternal Blood during Different Stages of Gestation. Fetal Diagn. Ther. 1998, 13, 375-379. [CrossRef] [PubMed]

14. Norton, M.E.; Bianchi, D.W. Prenatal diagnosis using fetal cells in the maternal circulation. In Prenatal Diagnosis and Reproductive Genetics; Kuller, J.A., Chescheir, N.C., Cefalo, R.C., Eds.; Mosby-Year Book: St Louis, MI, USA, 1996; pp. $228-235$. 
15. Krabchi, K.; Gros-Louis, F.; Yan, J.; Bronsard, M.; Masse, J.; Forest, J.-C.; Drouin, R. Quantification of all fetal nucleated cells in maternal blood between the 18th and 22nd weeks of pregnancy using molecular cytogenetic techniques. Clin. Genet. 2001, 60, 145-150. [CrossRef]

16. Nelson, J.L.; Furst, D.E.; Maloney, S. Microchimerism and HLA compatible relationships of pregnancy in sclerodermia. Lancet 1998, 351, 559-562. [CrossRef]

17. Bianchi, D.W.; Simpson, J.L.; Jackson, L.G.; Elias, S.; Holzgreve, W.; Evans, M.I.; Dukes, K.A.; Sullivan, L.M.; Klinger, K.W.; Bischoff, Z.F.; et al. Fetal gender and aneuploidy detection using fetal cells in maternal blood: Analysis of NIFTY I data. National Institute of Child Health and Development Fetal Cell Isolation Study. Prenat. Diagn. 2002, 22, 609-615. [CrossRef] [PubMed]

18. Krabchi, K.; Gadji, M.; Forest, J.-C.; Drouin, R. Quantification of all fetal nucleated cells in maternal blood in different cases of aneuploidies. Clin. Genet. 2006, 69, 145-154. [CrossRef] [PubMed]

19. Krabchi, K.; Gadji, M.; Samassékou, O.; Grégoire, M.-C.; Forest, J.-C.; Drouin, R. Quantification of fetal nucleated cells in maternal blood of pregnant women with a male trisomy 21 fetus using molecular cytogenetic techniques. Prenat. Diagn. 2005, 26, 28-34. [CrossRef]

20. Herzenberg, L.A.; Bianchi, D.W.; Schroder, J.; Cann, H.M.; Iverson, G.M. Fetal cells in the blood of pregnant women: Detection and enrichment by fluorescence-activated cell sorting. Proc. Natl. Acad. Sci. USA 1979, 76, 1453-1455. [CrossRef]

21. Bianchi, D.W.; Zickwolf, G.K.; Weil, G.J.; Sylvester, S.; DeMaria, M.A. Male fetal progenitor cells persist in maternal blood for as long as 27 years postpartum. Proc. Natl. Acad. Sci. USA 1996, 93, 705-708. [CrossRef]

22. Khosrotehrani, K.; Leduc, M.; Bachy, V.; Nguyen Huu, S.; Oster, M.; Abbas, A.; Uzan, S.; Aractingi, S. Pregnancy allows the transfer and differentiation of fetal lymphoid progenitors into functional T and B cells in mothers. J. Immunol. 2008, 180, 889-897. [CrossRef]

23. Jansen, M.W.; Korver-Hakkennes, K.; van Leenen, D.; Brandenburg, H.; Wildschut, H.I.; Wladimiroff, J.W.; Ploemacher, R.E. How useful is the in vitro expansion of fetal CD34+ progenitor cells from maternal blood samples for diagnostic purposes? Prenat. Diagn. 2000, 20, 725-731. [CrossRef]

24. Little, M.-T.; Langlois, S.; Wilson, R.D.; Lansdorp, P.M. Frequency of Fetal Cells in Sorted Subpopulations of Nucleated Erythroid and CD34+ Hematopoietic Progenitor Cells from Maternal Peripheral Blood. Blood 1997, 89, 2347-2358. [CrossRef]

25. Campagnoli, C.; Roberts, I.A.G.; Kumar, S.; Bennett, P.R.; Bellantuono, I.; Fisk, N. Identification of mesenchymal stem/progenitor cells in human first-trimester fetal blood, liver, and bone marrow. Blood 2001, 98, 2396-2402. [CrossRef]

26. Huu, S.N.; Dubernard, G.; Aractingi, S.; Khosrotehrani, K. Feto-Maternal Cell Trafficking: A Transfer of Pregnancy Associated Progenitor Cells. Stem Cell Rev. Rep. 2006, 2, 111-116. [CrossRef] [PubMed]

27. Mikhail, A.; Covic, A.; Goldsmith, D. Stimulating Erythropoiesis: Future Perspectives. Kidney Blood Press. Res. 2008, 31, 234-246. [CrossRef] [PubMed]

28. Klonisch, T.; Drouin, R. Fetal-maternal exchange of multipotent stem/progenitor cells: Microchimerism in diagnosis and disease. Trends Mol. Med. 2009, 15, 510-518. [CrossRef]

29. O’Donoghue, K.; Choolani, M.; Chan, J.; de la Fuente, J.; Kumar, S.; Campagnoli, C.; Bennett, P.R.; Roberts, I.A.G.; Fisk, N.M. Identification of fetal mesenchymal stem cells in maternal blood: Implications for non-invasive prenatal diagnosis. Mol. Hum. Reprod. 2003, 9, 497-502. [CrossRef] [PubMed]

30. de la Fuente, J.; O’Donoghue, K.; Kumar, S.; Chan, J.; Fisk, N.M.; Roberts, I.A.G. Ontogeny-related changes in integrin and cytokine production by fetal mesenchymal stem cells (MSC). Blood 2002, 100, 526a. [CrossRef]

31. Grosset, L.; Barrelet, V.; Odartchenko, N. Antenatal fetal sex determination from maternal blood during early pregnancy. Am. J. Obstet. Gynecol. 1974, 120, 60-63. [CrossRef]

32. Tharapel, A.T.; Jaswaney, V.L.; Dockter, M.E.; Wachtel, S.S.; Chandler, R.W.; Simpson, J.L.; Shulman, L.P.; Meyers, C.M.; Elias, S. Inability to detect fetal mataphases in flowsorted lynphocyte cultures based on maternal-fetal HLA differences. Fetl. Diagn. Ther. 1993, 8, 95-101. [CrossRef]

33. Parks, D.R.; Herzenberg, L.A. Fetal cells from maternal blood: Their selection and prospects for use in prenatal diagnosis. Methods Cell Biol. 1982, 26, 277-295. [PubMed]

34. Ganshirt-Ahlert, D.; Burschyk, M.; Garritsen, H.S.; Helmer, L.; Miny, P.; Horst, J.; Schneider, H.P.; Holzgreve, W. Magnetic cell sorting and the transferrin receptor as potential means of prenatal diagnosis from maternal blood. Am. J. Obstet. Gynecol. 1992, 166, 1350-1355. [CrossRef]

35. Choolani, M.; O’Donnell, H.; Campagnoli, C.; Kumar, S.; Roberts, I.; Bennet, P.R.; Fisk, N.M. Simultaneous fetal cell identification and diagnosis by $\varepsilon$-globin chain immunophenotyping and chromosomal fluorescence in situ hybridization. Blood 2001, 98 , 554-557. [CrossRef] [PubMed]

36. Kleinhauer, E.; Braun, H.; Betke, K. Demonstration of fetal hemoglobin in erythrocytes of a blood smear. Klin. Wochenschr. 1957, 35, 637-638. [CrossRef] [PubMed]

37. Sorensen, M.D.; Gonzalez Dosal, R.; Jensen, K.B.; Christensen, B.; Kolvraa, S.; Jensen, U.B.; Kristensen, P. Epsilon hemoglobin specific antibodies with applications in noninvasive prenatal diagnosis. J. Biomed. Biotechnol. 2009, 2009, 659219. [CrossRef]

38. Calabrese, G.; Baldi, M.; Fantasia, D.; Sessa, M.T.; Kalantar, M.; Holzhauer, C.; Alunni-Fabbroni, M.; Palka, G.; Sitar, G. Detection of chromosomal aneuploidies in fetal cells isolated from maternal blood using single-chromosome dual-probe FISH analysis. Clin. Genet. 2012, 82, 131-139. [CrossRef] 
39. Petit, C.; Fleurentin, A.; Fontaine, B.; Miton, A.; Lemarie, P.; Philippe, C.; Jonveaux, P. Use of the Kleihauer test to detect fetal erythroblasts in the maternal circulation. Prenat. Diagn. 2001, 21, 106-111. [CrossRef]

40. D'Souza, E.; Ghosh, K.; Colah, R. A comparison of the choice of monoclonal antibodies for recovery of fetal cells from maternal blood using FACS for noninvasive prenatal diagnosis of hemoglobinopathies. Cytom. Part B Clin. Cytom. 2008, 76, 175-180. [CrossRef]

41. Nemescu, D.; Constantinescu, D.; Gorduza, V.; Carauleanu, A.; Caba, L.; Navolan, D.B. Comparison between paramagnetic and CD71 magnetic actived cell sorting of fetal nucleated red blood cells from the maternal blood. J. Clin. Lab. Anal. 2020, 34, e23420. [CrossRef]

42. Zimmermann, S.; Hollmann, C.; Stachelhaus, S.A. Unique monoclonal antibodies specifically bind surface structures on human fetal erythroid blood cells. Exp. Cell Res. 2013, 319, 2700-2707. [CrossRef]

43. Wei, X.; Ao, Z.; Cheng, L.; He, Z.; Huang, Q.; Cai, B.; Rao, L.; Meng, Q.; Wang, Z.; Sun, Y.; et al. Highly sensitive and rapid isolation of fetal nucleated red blood cells with microbead-based selective sedimentation for non-invasive prenatal diagnostics. Nanotechnology 2018, 29, 434001. [CrossRef] [PubMed]

44. Johnson, P.; Molloy, C. Localization in Human Term Placental Bed and Amniochorion of Cells Bearing Trophoblast Antigens Identified by Monoclonal Antibodies. Am. J. Reprod. Immunol. 1983, 4, 33-37. [CrossRef]

45. Cacheux, V.; Milesi-Fluet, C.; Tachdjian, G.; Druart, L.; Bruch, J.F.; Hsi, B.L.; Uzan, S.; Nessmann, C. Detection of 47, XYY trophoblast fetal cells in maternal blood by fluorescence in situ hybridization after using immunomagnetic lymphocyte depletion and flow cytometry sorting. Fetal Diagn. Ther. 1992, 7, 190-194. [CrossRef]

46. Pötgens, A.J.; Schmitz, U.; Kaufmann, P.; Frank, H.-G. Monoclonal Antibody CD133-2 (AC141) Against Hematopoietic Stem Cell Antigen CD133 Shows Crossreactivity with Cytokeratin 18. J. Histochem. Cytochem. 2002, 50, 1131-1134. [CrossRef] [PubMed]

47. Kilpivaara, O.; Dhanjal, S.; Hulte'n, M.A. Cytotrophoblasts-specific antibodies for identification of fetal 76 cells in maternal blood. In Early Prenatal Diagnosis, Fetal Cells and DNA in the Mother; Karolinum Press: Prague, Czech Republic, $2002 ;$ pp. 34-39.

48. Kølvraa, S.; Singh, R.; Normand, E.A.; Qdaisat, S.; van den Veyver, I.B.; Jackson, L.; Hatt, L.; Schelde, P.; Uldbjerg, N.; Vestergaard, E.M.; et al. Genome-wide copy number analysis on DNA from fetal cells isolated from the blood of pregnant women. Prenat. Diagn. 2016, 36, 1127-1134. [CrossRef]

49. Guetta, E.; Gutstein-Abo, L.; Barkai, G. Trophoblasts isolated from the maternal circulation: In vitro expansion and potential application in non-invasive prenatal diagnosis. J. Histochem. Cytochem. 2005, 53, 337-339. [CrossRef]

50. van Wijk, I.J.; Griffioen, S.; Tjoa, M.L.; Mulders, M.A.; van Vugt, J.M.; Loke, Y.W.; Oudejans, C.B. HLA-G expression in trophoblast cells circulating in maternal peripheral blood during early pregnancy. Am. J. Obstet. Gynecol. 2001, 184, 991-997. [CrossRef]

51. Hatt, L.; Brinch, M.; Singh, R.; Møller, K.; Lauridsen, R.H.; Uldbjerg, N.; Huppertz, B.; Christensen, B.; Kølvraa, S. Characterization of fetal cells from the maternal circulation by microarray gene expression analysis-Could the extravillos trophoblasts be a target for future cell-based non-invasive prenatal diagnosis. Fetal Diagn. Ther. 2014, 35, 218-227. [CrossRef] [PubMed]

52. Sargent, I.L.; Choo, Y.S.; Redman, C.W. Isolating and analyzing fetal leukocytes in maternal blood. Ann. N. Y. Acad. Sci. 1994, 731, 147-153. [CrossRef]

53. Benirschke, K. Anatomical Relationship between Fetus and Mother. Ann. N. Y. Acad. Sci. 1994, 731, 9-20. [CrossRef]

54. Purwosunu, Y.; Sekizawa, A.; Koide, K.; Okazaki, S.; Farina, A.; Okai, T. Clinical potential for noninvasive prenatal diagnosis through detection of fetal cells in maternal blood. Taiwan. J. Obstet. Gynecol. 2006, 45, 10-20. [CrossRef]

55. Mouawia, H.; Saker, A.; Jais, J.-P.; Benachi, A.; Bussières, L.; Lacour, B.; Bonnefont, J.-P.; Frydman, R.; Simpson, J.L.; PaterliniBrechot, P. Circulating trophoblastic cells provide genetic diagnosis in 63 fetuses at risk for cystic fibrosis or spinal muscular atrophy. Reprod. Biomed. Online 2012, 25, 508-520. [CrossRef]

56. Gänshirt, D.; Garritsen, H.; Miny, P.; Holzgreve, W. Fetal cells in maternal circulation throughout gestation. Lancet 1994, 343, 1038-1039. [CrossRef]

57. Kavanagh, D.; Kersaudy-Kerhoas, M.; Dhariwal, R.; Desmulliez, M. Current and emerging techniques of fetal cell separation from maternal blood. J. Chromatogr. B 2010, 878, 1905-1911. [CrossRef] [PubMed]

58. Bianchi, D.W.; Flint, A.F.; Pizzimenti, M.F.; Knoll, J.H.; Latt, S.A. Isolation of fetal DNA from nucleated erythrocytes in maternal blood. Proc. Natl. Acad. Sci. USA 1990, 87, 3279-3283. [CrossRef] [PubMed]

59. Beaudet, A.L. Using fetal cells for prenatal diagnosis: History and recent progress. Am. J. Med. Genet. Part C Semin. Med. Genet. 2016, 172, 123-127. [CrossRef]

60. Sitar, G.; Brambati, B.; Baldi, M.; Montanari, L.; Vincitorio, M.; Tului, L.; Forabosco, A.; Ascari, E. The use of non-physiological conditions to isolate fetal cells from maternal blood. Exp. Cell Res. 2005, 302, 153-161. [CrossRef]

61. Twu, Y.C.; Chen, C.P.; Hsieh, C.Y.; Tzeng, C.H.; Sun, C.F.; Wang, S.H.; Chang, M.S.; Yu, L.C. I branching formation in erythroid differentiation is regulated by trascription factor C/EBPalpha. Blood 2007, 110, 4526-4534. [CrossRef]

62. Marsh, W.L. Antii: A cold antibody defining the Ii relationship in human red cells. Br. J. Haematol. 1961, 7, 200-209. [CrossRef]

63. Marsh, W.L.; Nichols, M.E.; Reid, M.E. The definition of two I antigen components. Vox Sang. 1971, 20, 209-217. [CrossRef]

64. Calabrese, G.; Fantasia, D.; Alfonsi, M.; Morizio, E.; Celentano, C.; Franchi, P.G.; Sabbatinelli, G.; Palka, C.; Benn, P.; Sitar, G. Aneuploidy screening using circulating fetal cells in maternal blood by dual-probe FISH protocol: A prospective feasibility study on a series of 172 pregnant women. Mol. Genet. Genom. Med. 2016, 4, 634-640. [CrossRef] [PubMed] 
65. Guanciali Franchi, P.; Palka, C.; Morizio, E.; Sabbatinelli, G.; Alfonsi, M.; Fantasia, D.; Sitar, G.; Benn, P.; Calabrese, G. Sequential combined test, second trimester maternal serum markers, and circulating fetal cells to select women for invasive prenatal diagnosis. PLoS ONE 2017, 12, e0189235. [CrossRef] [PubMed]

66. Von Koskull, H.; Gahmberg, N. Fetal erythroblasts from maternal blood identified with 2,3-bisphosphoglycerate (BPG) and in situ hybridization (ISH) using Y-specific probes. Prenat. Diagn. 1995, 15, 149-154. [CrossRef]

67. De Graaf, I.M.; Jakobs, M.E.; Leschot, N.J.; Ravkin, I.; Goldbard, S.; Hoovers, J.M.N. Enrichment, identification and analysis of fetal cells from maternal blood: Evaluation of a prenatal diagnosis system. Prenat. Diagn. 1999, 19, 648-652. [CrossRef]

68. Boyer, S.H.; Noyes, A.N.; Boyer, M.L. Enrichment of erythro-cytes of fetal origin from adult-fetal blood mixtures via selective hemolysis of adult blood cells: An aid to antenatal diagnosis of hemoglobinopathies. Blood 1976, 47, 883-897. [CrossRef]

69. Hengstschlager, M.; Bernaschek, G. Fetal cells in the peripheral blood of pregnant women express thymidine kinase: A new marker for detection. FEBS Lett. 1997, 404, 299-302. [CrossRef]

70. Kitagawa, M.; Sugiura, K.; Omi, H.; Akiyama, Y.; Kanayama, K.; Shinya, M.; Tanaka, T.; Yura, H.; Sago, H. New techniques using galactose-specific lectin for isolation of fetal cells from maternal blood. Prenat. Diagn. 2002, 22, 17-21. [CrossRef]

71. Wachi, T.; Katagawa, M. Studies on preliminary concentration methods for recovery of fetal nucleated red blood cells in maternal blood. Congenit. Anom. 2004, 44, 196-203. [CrossRef]

72. Valerio, D.; Aiello, R.; Altieri, V. Isolation of fetal erythroid cells from maternal blood based on expression of erythropoietin receptors. Mol. Hum. Reprod. 1997, 3, 451-455. [CrossRef]

73. Wachtel, S.S.; Sammons, D.; Manley, M.; Wachtel, G.; Twitty, G.; Utermohlen, J.; Phillips, O.P.; Shulman, L.P.; Taron, D.J.; Müller, U.R.; et al. Fetal cells in maternal blood: Recovery by charge flow separation. Hum. Genet. 1996, 98, 162-166. [CrossRef]

74. Wachtel, S.S.; Sammons, D.; Twitty, G.; Utermohlen, J.; Tolley, E.; Phillips, O.; Shulman, L.P. Charge flow separation: Quantification of nucleated red blood cells in maternal blood during pregnancy. Prenat. Diagn. 1998, 18, 455-463. [CrossRef]

75. Mohamed, H.; Turner, J.N.; Caggana, M. Biochip for separating fetal cells from maternal circulation. J. Chromatogr. A 2007, 1162, 187-192. [CrossRef] [PubMed]

76. Huang, R.; Barber, T.A.; Schmidt, M.A.; Tompkins, R.G.; Toner, M.; Bianchi, D.W.; Kapur, R.; Flejter, W.L. A microfluidics approach for the isolation of nucleated red blood cells (NRBCs) from the peripheral blood of pregnant women. Prenat. Diagn. 2008, 28, 892-899. [CrossRef]

77. Autebert, J.; Coudert, B.; Bidard, F.-C.; Pierga, J.-Y.; Descroix, S.; Malaquin, L.; Viovy, J.-L. Microfluidic: An innovative tool for efficient cell sorting. Methods 2012, 57, 297-307. [CrossRef] [PubMed]

78. Wang, Z.; Cheng, L.; Wei, X.; Cai, B.; Sun, Y.; Zhang, Y.; Liao, L.; Zhao, X.-Z. High-throughput isolation of fetal nucleated red blood cells by multifunctional microsphere-assisted inertial microfluidics. Biomed. Microdevices 2020, 22, 75. [CrossRef] [PubMed]

79. Huang, C.-E.; Ma, G.-C.; Jou, H.-J.; Lin, W.-H.; Lee, D.-J.; Lin, Y.-S.; Ginsberg, N.A.; Chen, H.-F.; Chang, F.M.-C.; Chen, M. Noninvasive prenatal diagnosis of fetal aneuploidy by circulating fetal nucleated red blood cells and extravillous trophoblasts using silicon-based nanostructured microfluidics. Mol. Cytogenet. 2017, 10, 44. [CrossRef] [PubMed]

80. Ma, G.-C.; Lin, W.-H.; Huang, C.-E.; Chang, T.-Y.; Liu, J.-Y.; Yang, Y.-J.; Lee, M.-H.; Wu, W.-J.; Chang, Y.-S.; Chen, M. A Siliconbased Coral-like Nanostructured Microfluidics to Isolate Rare Cells in Human Circulation: Validation by SK-BR-3 Cancer Cell Line and Its Utility in Circulating Fetal Nucleated Red Blood Cells. Micromachines 2019, 10, 132. [CrossRef]

81. Gur, O.; Chang, C.L.; Jain, R.; Zhong, Y.; Savran, C.A. High-purity isolation of rare single cells from blood using a tiered microchip system. PLoS ONE 2020, 15, e0229949. [CrossRef] [PubMed]

82. Sun, Y.; Cai, B.; Wei, X.; Wang, Z.; Rao, L.; Meng, Q.-F.; Liao, Q.; Liu, W.; Guo, S.; Zhao, X. A valve-based microfluidic device for on-chip single cell treatments. Electrophoresis 2018, 40, 961-968. [CrossRef]

83. Voullaire, L.; Ioannou, P.; Nouri, S.; Williamson, R. Fetal nucleated red blood cells from CVS washings: An aid to development of first trimester non-invasive prenatal diagnosis. Prenat. Diagn. 2001, 21, 827-834. [CrossRef]

84. Takabayashi, H.; Kuwabara, S.; Ukita, T.; Ikawa, K.; Yamafuji, K.; Igaras, T. Development of non-invasive fetal DNA diagnosis from maternal blood. Prenat. Diagn. 1995, 15, 74-77. [CrossRef] [PubMed]

85. Byeon, Y.; Ki, C.S.; Han, K.H. Isolation of nucleated red blood cells in maternal blood for Non-invasive prenatal diagnosis. Biomed Microdevices 2015, 17, 118. [CrossRef] [PubMed]

86. Henkelman, S.; Rakhorst, G.; van der Mei, H.C.; Busscher, H.J. Use of hydroxyethyl starch for inducing red blood cell aggregation. Clin. Hemorheol. Microcirc. 2012, 52, 27-35. [CrossRef]

87. Vona, G.; Beroud, C.; Benachi, A.; Quenette, A.; Bonnefont, J.-P.; Romana, S.P.; Dumez, Y.; Lacour, B.; Paterlini-Bréchot, P. Enrichment, Immunomorphological, and Genetic Characterization of Fetal Cells Circulating in Maternal Blood. Am. J. Pathol. 2002, 160, 51-58. [CrossRef]

88. Béroud, C.; Karliova, M.; Bonnefont, J.; Benachi, A.; Munnich, A.; Dumez, Y.; Lacour, B.; Paterlini-Bréchot, P. Prenatal diagnosis of spinal muscular atrophy by genetic analysis of circulating fetal cells. Lancet 2003, 361, 1013-1014. [CrossRef]

89. Saker, A.; Benachi, A.; Bonnefont, J.P.; Munnich, A.; Dumez, Y.; Lacour, B.; Paterlini-Brechot, P. Genetic characterisation of circulating fetal cells allows non-invasive prenatal diagnosis of cystic fibrosis. Prenat. Diagn. 2006, 26, 906-916. [CrossRef]

90. Bolnick, J.M.; Kilburn, B.A.; Bajpayee, S.; Reddy, N.; Jeelani, R.; Crone, B.; Simmerman, N.; Singh, M.; Diamond, M.; Armant, D.R. Trophoblast retrieval and isolation from the cervix (TRIC) for noninvasive prenatal screening at 5 to 20 weeks of gestation. Fertil. Steril. 2014, 102, 135-142.e6. [CrossRef] 
91. Fritz, R.; Kohan-Ghadr, H.R.; Sacher, A.; Bolnick, A.D.; Kilburn, B.A.; Bolnick, J.M.; Diamond, M.P.; Drewlo, S.; Armant, D.R. Trophoblast retrieval and isolation from the cervix (TRIC) is unaffected by early gestational age or maternal obesity. Prenat. Diagn. 2015, 35, 1218-1222. [CrossRef]

92. Hall, J.M.; Adams, S.; Williams, S.; Rehse, M.A.; Layton, T.J.; Molesh, D.A. Purification of fetal cells from maternal blood using an avidin-biotin immunoaffinity column. Ann. N. Y. Acad. Sci. 1994, 731, 115-127. [CrossRef]

93. Hultén, M.A.; Dhanjal, S. A novel assay for rapid and simple non-invasive prenatal diagnosis of genetic anomalies. In Early Prenatal Diagnosis, Fetal Cells and DNA in the Mother; Karolinum Press: Prague, Czech Republic, 2002; pp. 59-71.

94. Evans, M.I.; Sharp, M.; Tepperberg, J.; Kilpatrick, M.W.; Tsipouras, P.; Tafas, T. Automated Microscopy of Amniotic Fluid Cells: Detection of FISH Signals Using the FastFISH ${ }^{\circledR}$ Imaging System. Fetal Diagn. Ther. 2006, 21, 523-527. [CrossRef] 